\title{
Effect of hyperbaric oxygen therapy in rats with subtotal splenectomy preserving the inferior pole ${ }^{1}$
}

\author{
Efeito da oxigenoterapia hiperbárica em ratos submetidos à esplenectomia \\ subtotal com preservação do polo inferior
}

\author{
Marcela Souza Lima PauloI, Isabel Cristina Andreatta Lemos PauloII, Tarcizo Afonso Nunes ${ }^{\mathrm{III}}$, Alcino Lázaro da Silva ${ }^{\mathrm{IV}}$, Luiz \\ Cálice Cintrav', Danilo Nagib Salomão Paulovi
}

${ }^{1}$ Experimentation Laboratory Animal, Research Center, School of Science, EMESCAM, Vitoria-ES, Brazil.

\begin{abstract}
${ }^{I}$ Master in Basic Sciences, EMESCAM, Vitoria-ES, Brazil. Responsible for manuscript preparation, acquisition and interpretation of data. The article is part of master thesis level.

II Associate Professor, Department of Surgery, School of Sciences, EMESCAM, Vitoria-ES Brazil. Responsible for manuscript preparation, critical revision.

III PhD, Associate Professor, Medical School, Federal University of Minas Gerais (UFMG), Minas Gerais-MG, Brazil. Advisor, conception and design of the study.

${ }^{\text {IV }}$ Emeritus Professor of Surgery, School of Medicine, UFMG, Vitoria-ES, Brazil. Supervised all phases of the study.

${ }^{\mathrm{v}}$ Associate Professor, Department of Pathology, School of Science, EMESCAM, Vitoria-ES, Brazil. Acquisition and interpretation of data.

${ }^{\mathrm{V}}$ Full Professor of Surgery, Department of Surgery, School of Sciences, EMESCAM, Vitoria-ES, Brazil. Conception, design, intellectual and scientific content of the study, manuscript writing, statistical analysis.
\end{abstract}

\begin{abstract}
Purpose: To evaluate the effect of hyperbaric oxygen therapy on the survival and weight of rats submitted to subtotal splenectomy and on the viability and growth of the inferior pole. Methods: Forty Wistar rats underwent subtotal splenectomy with preservation of the inferior pole and distributed into two groups: Group A $(n=20)$ - not treated with hyperbaric oxygen, Group B (n=20) - treated with hyperbaric oxygen. These groups were divided into two subgroups of 10 animals each, according to the time of euthanasia, $15^{\text {th }}$ and $45^{\text {th }}$ days. The survival and weight of the animals were recorded. The inferior pole was measured, weighed and morphologically analyzed. Results: All animals survived. The weight of the animals increased in all subgroups, but decreased on the $10^{\text {th }}$ day in the subgroups treated with hyperbaric oxygen $(\mathrm{p}<0.001)$. The viability of the inferior pole was more evident in animals treated on the $15^{\text {th }}$ day, but did not differ on the $45^{\text {th }}$ day. The growth of the inferior pole has not occurred on the $15^{\text {th }}$ day but on the $45^{\text {th }}$ day after surgery in untreated animals $(\mathrm{p}<0.01)$ and treated animals $(\mathrm{p}<0.05)$. Vascular and cellular increase in treated animals was significantly higher than in untreated ones. Conclusion: Hyperbaric oxygen therapy did not affect the survival of animals but reduced their weight. It improved the viability of the inferior splenic pole, but did not interfere with their growth.
\end{abstract}

Key words: Splenectomy/adverse effects. Splenectomy/methods. Hyperbaric Oxygenation. Animal Experimentation.

\section{RESUMO}

Objetivo: Avaliar o efeito da oxigenoterapia hiperbárica na sobrevida e peso de ratos submetidos à esplenectomia subtotal e na viabilidade e crescimento do polo inferior. Métodos: Quarenta ratos Wistar foram submetidos à esplenectomia subtotal com preservação do polo inferior e distribuídos em dois grupos: $A(n=20) v$ - não tratados com oxigênio hiperbárico, $B(n=20)$ - tratados. Esses grupos foram divididos em dois subgrupos de 10 animais cada, de acordo com a época de eutanásia: $15^{\circ}$ e $45^{\circ}$ dias. A sobrevida e peso dos animais foram anotadas. O pólo inferior foi medido, pesado e analisado morfologicamente. Resultados: Todos os animais sobreviveram. O peso aumentou em todos os subgrupos, porém diminuiu no $10^{\circ}$ dia nos subgrupos tratados com oxigênio hiperbárico $(\mathrm{p}<0,001)$. A viabilidade do polo inferior foi mais evidente nos animais tratados no $15^{\circ}$ dia, porém não diferiu no $45^{\circ}$ dia. O crescimento do polo inferior não ocorreu no $15^{\circ}$ e sim no $45^{\circ}$ dia pós-operatório, nos animais não tratados $(p<0,01)$ e tratados $(p<0,05)$. O aumento celular e vascular nos animais tratados foi mais significativo do que nos animais não tratados. Conclusão: A oxigenoterapia hiperbárica não interferiu na sobrevida dos animais, porém diminuiu o peso. Melhorou a viabilidade do polo inferior do baço, mas não interferiu no seu crescimento. Descritores: Esplenectomia/efeitos adversos. Esplenectomia/métodos. Oxigenação Hiperbárica. Experimentação Animal. 


\section{Introduction}

For many years, the spleen, an organ of the reticuloendothelial system was considered non-essential to life and, therefore, its removal should not cause serious damage to the patient ${ }^{1,2}$. In1952, King and Shumacker $\mathrm{Jr}^{3}$ reported the association between total splenectomy and the occurrence of sepsis in children. Since then, the risks of infection after splenectomy have been observed in children and adults, especially in the first two years after surgery ${ }^{4}$. Complicated infections after splenectomy were also observed in experimental animals ${ }^{5}$. Absence of the spleen is related to alterations in lipid metabolism in humans ${ }^{6,7}$ and in laboratory animals ${ }^{8-11}$ thus causing atherosclerosis ${ }^{8}$.

In addition to the functions assigned to the spleen, many others are certainly still unknown, which strengthens the need to preserve all or part of it by splenorrhaphies ${ }^{2}$, vascular occlusions ${ }^{12-14}$, partial splenectomies ${ }^{15-17}$ and autoimplants ${ }^{18-19}$. The most recently described procedure is subtotal splenectomy with the preservation of the inferior pole (STPI) ${ }^{17}$. In this technique, the blood supply is maintained through the vessels of the gastrosplenic ligament. This operation was performed in $\operatorname{dogs}{ }^{17}$ and in rats ${ }^{20}$ and an evaluation of the inferior pole in the immediate postoperative period, showed changes in the viability of the remaining tissue, in some cases accompanied by changes in the lipid function ${ }^{17-21}$. In the late postoperative period there was marked follicular hyperplasia and increased cell population of the inferior pole in dogs on the $60^{\text {th }}$ day ${ }^{17}$. Paulo et al. ${ }^{22}$ observed the growth of the remaining tissue on the $80^{\text {th }}$ day. STPI performed in other models than the one described in our work, showed that the histological pattern of this pole becomes similar to normal splenic tissue in 45 $\operatorname{dias}^{23}$. It's unclear, however, to which factor these changes can be attributed. A recent study showed that, on the $11^{\text {th }}$ day after surgery, the animals treated with hyperbaric oxygen (HBO) had improved the lipid function and the viability of the inferior splenic pole in comparison with untreated animals ${ }^{24}$. On the $70^{\text {th }}$ day after surgery, however, there was no influence of the hyperbaric oxygen therapy on the viability of that polo ${ }^{24}$.

In experimental studies it was found that hyperbaric oxygen therapy (HBO) has an angiogenic effect ${ }^{25}$, stimulates collateral circulation ${ }^{26}$, decreases the deleterious effects on liver and spleen in rats submitted to hepatic veins ligature with increased survival ${ }^{27}$ and improves the outcome of transplantation of pancretic islets ${ }^{27}$. Considering these facts, it was questioned whether this therapeutic approach could actually interfere with the viability and hence with the growth of the remaining inferior pole, after the operation. Thus, it would be possible to restore some or all the functions of the spleen, avoiding the complications of splenic dysfunction.

Another relevant aspect to be studied concerns the analysis of the effects of hyperbaric oxygen therapy on the evolution and survival of animals. In a previous work $^{29}$, the rats that underwent STPI and were treated with hyperbaric oxygen for 10 days showed significant weight loss on the $11^{\text {th }}$ day after surgery. Moreover, these rats had a shorter survival than those that were not treated, although in a non-significant way. In order to investigate these issues, we decided to study the effect of hyperbaric oxygen therapy in rats submitted to subtotal splenectomy taking into consideration the following aspects: animals' weight and survival, and viability and growth of the inferior splenic pole.

\section{Methods}

This work was performed at the Laboratory of Animal Experimentation, Research Center of the School of Sciences of Santa Casa de Misericordia de Vitoria - ES (EMESCAM). Animal manipulation followed the recommendations of the Brazilian Society of Laboratory Animal Science (SBCAL/COBEA), and was approved by the Ethics Research Committee of the Federal University of Minas Gerais, according to ETIC document $n^{\circ}$ 004/2008.

\section{Sample characteristics and animal care}

Forty male Wistar rats weighing between 274 and $313 \mathrm{~g}$ $(294.15 \pm 10.33 \mathrm{~g})$ were used. They were obtained at the Animal Production Vivarium of the Research Center of EMESCAM. The animals were kept in appropriate cages and properly identified and maintained in STD 5 Vivarium Cabinet (Vidy Group - Sao Paulo, Brazil) under appropriate conditions such as acclimatization, temperature $\left(20\right.$ to $\left.22{ }^{\circ} \mathrm{C}\right)$, ventilation and light (12 hours light and 12 hours dark) control. The animals received rat chow (CR-1 Nuvilab autoclavable - Nuvital ${ }^{\circledR}$ ) and water ad libitum at all stages of the experiment.

\section{Animal group formation}

The animals were distributed at random into two groups: those that were treated with hyperbaric oxygen and those who were not treated. Each group was divided into two subgroups according to the day of euthanasia in the postoperative period:

- Group A ( $\mathrm{n}=20)$ - not submitted to hyperbaric oxygen therapy 
- A15 subgroup ( $\mathrm{n}=10)$ - euthanasia on $15^{\text {th }}$ day after surgery;

- A45 subgroup $(n=10)$ - euthanasia on $45^{\text {th }}$ day after surgery;

- Group B ( $\mathrm{n}=20)$ - submitted to hyperbaric oxygen therapy

- B15 subgroup $(n=10)$ - euthanasia on $15^{\text {th }}$ day after surgery;

- B45 subgroup $(n=10)$ - euthanasia on $45^{\text {th }}$ day after surgery.

The animals were housed in groups of four in each cage, identified according to the group and subgroup. The animals were individually monitored throughout the experiment and information on each animal was recorded.

Anesthesia and splenectomy with preservation of the inferior pole

The surgical procedure was the same for all 40 animals in the experiment and the surgeon did not know which animals were assigned to each group.

After fasting for six hours, the animals were weighed (electronic scale Filizola ${ }^{\circledR}$ model MF-6 - sensitivity to $1 \mathrm{~g}$ ) and anesthetized with ketamine hydrochloride $\left(\operatorname{Vetaset}^{\circledR}\right.$, Fort DodgeIowa, USA) at a dose of $50 \mathrm{mg} / \mathrm{kg}$ associated with xylazine hydrochloride (Kensol ${ }^{\circledR}$, König-Avellaneda, Argentina) at a dose of $5 \mathrm{mg} / \mathrm{kg}$ applied intraperitoneally. The rats were immobilized on the surgical table, had their chest and abdominal wall shaved and underwent antisepsis with topical Polvidine.

The surgical procedure consisted of: a) midline laparotomy approximately $2.5 \mathrm{~cm}$ in length, which started $0.5 \mathrm{~cm}$ below the xiphoid process; b) exploration of the abdominal cavity and mobilization of the spleen to the surface of the abdominal cavity; c) ligation and sectioning of vessels that irrigate the upper and middle portion of the spleen, close to the splenic surface, with mononylon 6.0 (Shalom $^{\circledR}$, Shalom Wire Surgical Ltda, Goias, Brazil); d) sectioning of the spleen below the lacquered vessels, keeping the wound unsutured and without omentum protection and inferior pole irrigated by vessels of the gastrosplenic ligament ${ }^{17}$ (Figure 1); e) measuring the spleen's inferior pole in its central part, as to length, width and thickness, using plastic caliper; f) suturing of the abdominal wall in plans, using mononylon 6.0 (Shalom ${ }^{\circledR}$, Shalom Wire Surgical Ltda, Goias, Brazil).

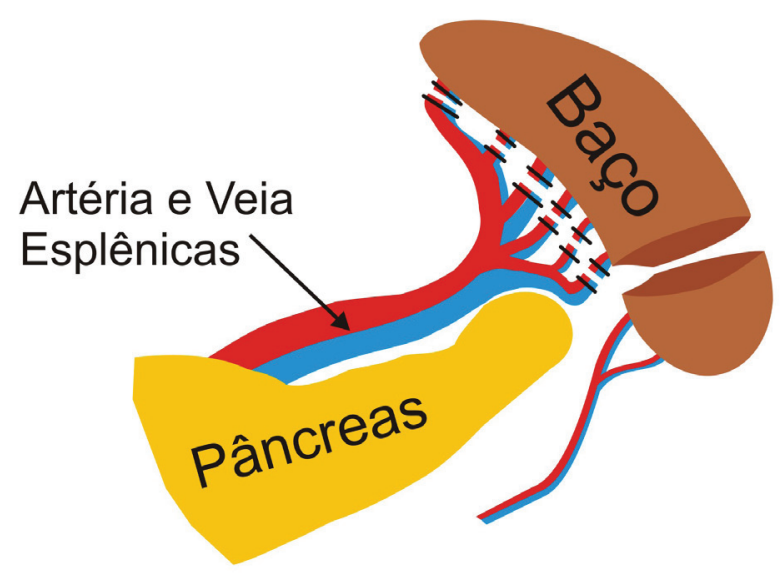

FIGURE 1 - Diagram showing the vascular ligatures close to the spleen and the splenic section, with the removal of the upper portion and inferior pole maintance (Courtesy of Isabel Cristina Andreatta Lemos Paulo).

At surgery, $5 \mathrm{~mL}$ of $0.9 \%$ saline were administered subcutaneously and repeated every 24 hours for two days, aiming at fluid replacement.

The upper portion of the excised spleen was fixed in neutral 10\% buffered formalin (potential of Hydrogen - $\mathrm{pH}$ 7) 24 to 48 hours and processed in paraffin for histological analysis. This splenic tissue was used to control the inferior splenic pole for microscopic examination.

\section{Postoperatory}

After the surgical procedures, the animals, still anesthetized, were identified with ear tags and returned to their cages of origin. The animals received water and food ad libitum and $200 \mathrm{mg} / \mathrm{kg}$ paracetamol (Tylenol ${ }^{\circledR}$, Janssen-Cilag, Sao Paulo, Brazil) orally, dissolved in their drinking water, for 72 hours. The evolution of the animals was monitored throughout the postoperative period.

\section{Hyperbaric oxygentherapy (HBO)}

Hyperbaric oxygentherapy was performed only in group $\mathrm{B}$, according to the protocol ${ }^{30}$. Immediately after recovery from anesthesia, the rats were placed in the hyperbaric chamber; where oxygen pressure was progressively adjusted for 15 minutes to up to 2.5 atmospheres. Animals were exposed to this therapy for 90 minutes, followed by exposition to gradual decompression chamber for 15 minutes. This procedure was performed twice daily during the first three days and once daily for seven days. 


\section{Euthanasia and removal of the remaining splenic tissue}

At the $15^{\text {th }}$ and $45^{\text {th }}$ days of the postoperative period, the rats of group A and group B were weighed (electronic scale Filizola ${ }^{\circledR}$ model MF-6 - sensitivity of $1 \mathrm{~g}$ ) and intraperitoneally anesthetized with sodium thiopental (Thiopentax ${ }^{\circledR}$, Cristalia, Sao Paulo, Brazil) at a dose of $50 \mathrm{mg} / \mathrm{kg}$. The animals were then euthanized with a lethal dose of sodium thiopental and $10 \%$ potassium chloride 10\% (Farmace, Ceara, Brazil), intracardiac $(300 \mathrm{mg} / \mathrm{kg})$. The animals underwent laparotomy through an inverted " $U$ " incision in the abdominal wall. In the exploration of the cavity, the abdominal viscera were inspected as well as the presence or absence of adhesions and the aspect of the inferior splenic pole. The remaining splenic tissue was excised for examination.

\section{Measurement and weighing of the inferior splenic pole}

Before its removal, the central part of the inferior pole was measured (length, width, thickness) with a plastic caliper, the same way it was done during subtotal splenectomy. After the removal of the inferior pole it was weighed to $0.001 \mathrm{~g}$ precision on an Adventurer OHAUS model AR 3130 balance (Sao Paulo, Brazil). Information on each animal (measure and weight of the inferior pole) was recorded.

\section{Macroscopic examination}

The inferior splenic pole of each animal was macroscopically examined for color, consistency and presence or absence of necrosis. The specimen was photographed and fixed in $10 \%$ neutral formaldehyde solution ( $\mathrm{pH} 7$ ) 24 to 48 hours and processed in paraffin for morphological analysis.

\section{Microscopic examination}

The fragments of the superior portion (upper and middle) and the inferior splenic pole were processed in $3 \mu \mathrm{m}$ thick paraffin blocks and stained with hematoxylin-eosin. The microscopy was performed with binocular microscopes by two pathologists who did not know to which subgroup the animals belonged. 10 slides were analyzed in subgroup A15, 10 in subgroup A45, 10 in subgroup B15 and 10 in subgroup B45 and 10 slides with the tissue of the superior portion of the spleen at random selection (control). In each slide pathologists examined 10 random fields $(100 \mathrm{X})$ and investigated the following parameters: lymphatic follicles (germinal centers), number of lymphocytes, number of sinusoids, cellular proliferation and blood vessels.

\section{Variables studied and statistical tests}

Descriptive statistics was used to calculate the arithmetic mean and standard deviation of the rats' weight as well as the weight, length, width and thickness of the inferior splenic pole.

Student's t-test for related samples was used to compare the weight of animals in groups $\mathrm{A}$ and $\mathrm{B}$, preoperatively to postoperatively $\left(10^{\text {th }}, 15^{\text {th }}\right.$ and $45^{\text {th }}$ day). This test was also used to compare the length, width and thickness of the inferior splenic pole of animals in groups treated or not treated with hyperbaric oxygen, from the beginning to the end of the experiment.

Student's t-test for independent samples was used to compare the weight of the inferior pole of the animals treated with hyperbaric oxygen with those that were untreated.

Fisher's exact test was utilized to compare the frequency of the feasibility of the inferior pole of the animals treated with hyperbaric oxygen with that of untreated animals.

All tests were two-tailed and $\mathrm{P}$ values were considered significant when equal or less than $5 \%$.

\section{Results}

Survival of animals and examination of the abdominal cavity

There were no deaths in both groups. The abdominal viscera showed no changes from the first surgery (intraoperative). Adhesions of the inferior splenic pole to the neighboring structures (stomach, greater omentum) were noted in all animals treated or not with hyperbaric oxygen.

\section{Weight of animals}

The weight of the animals in the group that was not treated with hyperbaric oxygen increased significantly at the end of the experiment compared to its beginning (Subgroups A15 $p<0.0001$ and $A 45 p<0.0001)$. In animals treated with hyperbaric oxygen, B15 and B45 subgroups, there was weight loss on the $1^{\text {st }}$ to the $10^{\text {th }}$ day postoperatively $(\mathrm{p}<0.01)$ and subsequently the animals gained weight $(\mathrm{p}<0.0001)$ (Table 1$)$. 
TABLE 1 - Rat weight (g) in groups treated and not treated with hyperbaric oxygen in the preoperative period, at the $10^{\text {th }}$ day and at the postoperative period, submitted to subtotal splenectomy with the preservation of the inferior pole.

\begin{tabular}{|c|c|c|c|c|c|c|c|}
\hline Group & Subgroup & $\begin{array}{c}\text { Preoperative } \\
\text { AM SD }\end{array}$ & $\begin{array}{l}10^{\text {th }} \text { day } \\
\text { AM SD }\end{array}$ & $p$ & $\begin{array}{c}\text { Postoperative } \\
\text { AM SD }\end{array}$ & $p_{I}$ & $p_{2}$ \\
\hline \multirow[t]{2}{*}{ A } & A 15 & $302.80 \pm 8.54$ & $\begin{array}{c}319.90 \pm \\
9.80\end{array}$ & $<0.0001$ & $339.40 \pm 8.26$ & $<0.0001$ & $<0.0001$ \\
\hline & A45 & $294.40 \pm 4.52$ & $\begin{array}{c}314.30 \pm \\
6.05\end{array}$ & $<0.0001$ & $382.50 \pm 18.43$ & $<0.0001$ & $<0.0001$ \\
\hline \multirow[t]{2}{*}{ B } & B15 & $293.33 \pm 11.73$ & $\begin{array}{c}288.22 \pm \\
9.99\end{array}$ & $<0.01$ & $309.44 \pm 14.96$ & $<0.0001$ & $<0.0001$ \\
\hline & B45 & $286.00 \pm 8.76$ & $\begin{array}{c}281.10 \pm \\
10.50\end{array}$ & $<0.01$ & $412.10 \pm 27.40$ & $<0.0001$ & $<0.0001$ \\
\hline
\end{tabular}

AM - Arithmetic Mean; SD - Standard Deviation. T test for related samples. $p \leq 0.05$ significant; $\boldsymbol{p}$-comparison between the weight of animals of the same subgroup, between the preoperative period and the $10^{\text {th }}$ day of the experiment;

$p_{1}$ - comparison between the weight of the animals of the same subgroup, between the preoperative and postoperative periods of the experiment;

$\boldsymbol{p}_{2}$ - comparison between the weight of animals of the same subgroup, between the $10^{\text {th }}$ day and postoperative period of the experiment.

\section{Weight of the remaining inferior pole}

The weight of the inferior splenic pole increased significantly only in animals not treated with hyperbaric oxygen (A15 and A45 subgroups), ( $\left.p_{1}<0.01\right)$. In the other comparisons that variable did not change significantly (Table 2 ).

TABLE 2 - Final weight of the inferior splenic pole in rats treated and untreated with hyperbaric oxygen in the mediate postoperative period $\left(15^{\text {th }}\right.$ day) and in the late postoperative period ( $45^{\text {th }}$ day) who underwent subtotal splenectomy, with the preservation the inferior pole.

\begin{tabular}{c|c|c|c|c|c}
\hline \multirow{2}{*}{ Group } & \multirow{2}{*}{ Subgroup } & \multicolumn{2}{|c|}{ Final weight } & \multirow{2}{*}{$\boldsymbol{p}_{1}$} & \multirow{2}{*}{$\boldsymbol{P}_{2}$} \\
\cline { 3 - 4 } & & AM & SD & & \\
\hline \multirow{2}{*}{ A } & A15 & $170.00 \pm 101.90$ & $<0.01$ & $>0.05$ \\
& A45 & $303.10 \pm 68.81$ & & \\
\hline \multirow{2}{*}{ B } & B15 & $162.55 \pm 68.70$ & $>0.05$ & $>0.05$ \\
& B45 & $219.80 \pm 117.11$ & & \\
\hline
\end{tabular}

AM - Arithmetic Mean; SD - Standard Deviation. T test for independent samples. $\mathrm{p} \leq 0.05$ significant.

$\boldsymbol{p}_{1}$ - comparison between the A15 and A45 subgroups and comparison between subgroups B15 and B45, at the end of the experiment.

$\boldsymbol{p}_{2}$ - comparison between the A15 and B15 subgroups and comparison between subgroups A45 and B45 at the end of the experiment.

\section{Measures of the remaining inferior pole}

The length of the inferior splenic pole increased significantly from the beginning to the end of the experiment only in animals not treated with hyperbaric oxygen and which were euthanized at the $45^{\text {th }}$ day $(A 45)(p<0.01)$. In other subgroups, this variable did not change $(\mathrm{p}>0.05)$ (Table 3$)$.

TABLE 3 - Length of the inferior splenic pole in rats treated and not treated with hyperbaric oxygen in the mediate preoperative and mediate postoperative periods $\left(15^{\text {th }}\right.$ day)and in the late preoperative and late postoperative periods ( $45^{\text {th }}$ day) that underwent subtotal splenectomy with the preservation of the inferior pole.

\begin{tabular}{c|c|c|c|c|c|c}
\hline \multirow{2}{*}{ Groups } & \multirow{2}{*}{ Subgroups } & \multicolumn{2}{|c|}{ Initial lenght } & \multicolumn{2}{|c|}{ Final lenght } & \multirow{2}{*}{$\boldsymbol{p}$} \\
\cline { 3 - 5 } & & AM & SD & AM & SD & \\
\hline \multirow{2}{*}{$\mathrm{A}$} & $\mathrm{A} 15$ & $9.90 \pm 2.07$ & $8.60 \pm 1.50$ & $>0.05$ \\
& $\mathrm{~A} 45$ & $10.10 \pm 1.28$ & $11.70 \pm 1.70$ & $<0.01$ \\
\hline \multirow{2}{*}{$\mathrm{B}$} & $\mathrm{B} 15$ & $8.44 \pm 1.57$ & $8.22 \pm 1.78$ & $>0.05$ \\
& $\mathrm{~B} 45$ & $8.90 \pm 1.66$ & $10.35 \pm 2.22$ & $>0.05$ \\
\hline
\end{tabular}

AM - Arithmetic Mean; SD - Standard Deviation. $\mathrm{p} \leq 0.05$ significant. $\boldsymbol{p}$ - comparison between the length of the inferior pole of the animals of the same subgroup, from the beginning to the end of the experiment. T test for related samples. $\mathrm{p} \leq 0.05$.

significant

The width of the inferior pole showed no significant changes in all subgroups from the beginning to the end of the experiment $(\mathrm{p}>0.05)$ (Table 4$)$.

TABLE 4 - Width of the inferior splenic pole in rats treated or not with hyperbaric oxygen in the mediate preoperative period and the mediate postoperative period $\left(15^{\text {th }}\right.$ day $)$ and in the late preoperative period and late postoperative period $\left(45^{\text {th }}\right.$ day) whounderwent subtotal splenectomy with the preservation of the inferior pole.

\begin{tabular}{c|c|c|c|c|c|c}
\hline \multirow{2}{*}{ Grupos } & \multirow{2}{*}{ Subgrupos } & \multicolumn{2}{|c|}{ Largura inicial } & \multicolumn{2}{c|}{ Largura final } & \multirow{2}{*}{ P } \\
\cline { 3 - 5 } & & MA & DP & MA & DP & \\
\hline \multirow{2}{*}{ A } & A15 & $8.50 \pm 1.17$ & $7.50 \pm 1.95$ & $>0.05$ \\
& A45 & $8,50 \pm 0,52$ & $9,30 \pm 1,05$ & $>0,05$ \\
\hline \multirow{2}{*}{ B } & B15 & $7.66 \pm 0.66$ & $7.50 \pm 1.93$ & $>0.05$ \\
& B45 & $7.90 \pm 0.99$ & $9.05 \pm 1.69$ & $>0.05$ \\
\hline
\end{tabular}

AM - Arithmetic Mean; DP - Standard Deviation

$\boldsymbol{p}$ - comparison between the width of the inferior pole of the animals of the same subgroup, from the beginning and the end of experiment. t-Test for related samples $\mathrm{p} \leq 0.05$ significant. 
The thickness of the inferior splenic pole increased significantly only in animals treated with hyperbaric oxygen and euthanized on $45^{\text {th }}$ day (B45). In the other subgroups, that variable did not change significantly $(\mathrm{p}>0.05)$.

TABLE 5 - Thickness of the inferior splenic pole in rats treated and not treated with hyperbaric oxygen in the mediate preoperative and mediate postoperative periods $\left(15^{\text {th }}\right.$ day) and late preoperative and late postoperative periods ( $45^{\text {th }}$ day) who underwent subtotal splenectomy with the preservation of the inferior pole.

\begin{tabular}{c|c|c|c|c|c|c}
\hline \multirow{2}{*}{ Groups } & \multirow{2}{*}{ Subgroups } & \multicolumn{2}{|l|}{ Initial thickness } & \multicolumn{2}{l|}{ Final thickness } & \multirow{2}{*}{ p } \\
\cline { 3 - 5 } & & AM & SD & AM & SD & \\
\hline \multirow{2}{*}{ A } & A15 & $4.20 \pm 0.91$ & $3.35 \pm 1.05$ & $>0.05$ \\
& A45 & $4.00 \pm 0.81$ & $4.45 \pm 0.89$ & $>0.05$ \\
\hline \multirow{2}{*}{ B } & B15 & $3.44 \pm 0.46$ & $3.61 \pm 0.74$ & $>0.05$ \\
& B45 & $3.15 \pm 0.57$ & $4.35 \pm 1.13$ & $<0.05$ \\
\hline
\end{tabular}

AM - Arithmetic Mean. SD - Standard Deviation.

$\boldsymbol{p}$ - comparison between the thickness of the inferior pole of the animals of the same subgroup, between the beginning and end of the experiment. T-test for related samples; $\mathrm{p} \leq 0.05$ significant.

\section{Macroscopic evaluation of the inferior splenic pole}

In eight animals that underwent hyperbaric oxygen therapy (subgroup A15) the macroscopic appearance of the inferior pole was normal and in $60 \%$ of the cases adhesions were found at the hepatic lobe and the intestinal loops. Vessels were observed at the periphery of the inferior splenic pole adhered to the omentum. In two animals of this subgroup (20\%) necrosis was observed at the end and central portion of the inferior pole. In the rats of subgroup A45, the macroscopic appearance of the inferior pole was normal in all cases, with vascularized adhesions on the greater omentum, intestinal loops and liver. Only one case was described as showing few adhesions.

In animals submitted to hyperbaric oxygen therapy (subgroup B15), the macroscopic appearance of the inferior pole was considered viable, with vascularized adhesions by the greater omentum, intestinal loops and liver. In the animals of subgroup $\mathrm{B} 45$, the macroscopic aspect of the inferior pole was considered feasible in all cases, with vascularized adhesions by the greater omentum, intestinal loops and liver. There was no macroscopic difference between subgroups A45 and B45.

\section{Microscopic evaluation of the inferior splenic pole}

Lymph follicles were larger and more frequent in the inferior pole of the animals in subgroup A15 than in the superior portion of the spleen (control). These follicles were larger in the inferior pole of animals of the subgroups A45, B15, B45 than in the animals of subgroup A15 and in the superior splenic portion (control). The presence of lymphocytes was more frequent in the inferior splenic pole of the animals in subgroup A15 than in the superior portion (control).

There was a greater amount of lymphocytes in subgroups A45, B15 and B45 than in the superior portion (control). There was no marked difference in the amount of sinusoids between the superior splenic portion (control) and the inferior pole of the four subgroups in a conventional morphological study. However, the cellular and vascular increase in subgroups B15 and B45 is noteworthy when compared to the inferior pole of the A15 and A45 subgroups. Cell proliferation was more pronounced in the inferior pole of the A15 subgroup than in the superior portion (control) and was less intense in the superior portion (control) than in other subgroups.

There was an increase of lymphocyte cell proliferation in subgroup A45, B15 and B45. The presence of cells in the wall and inside the vessels was more intense in the inferior pole of the B15 and B45 subgroups and occurred with less intensity in the superior splenic portion, which was excised in partial splenectomy.

\section{Discussion}

Preservation of splenic tissue is important to avoid immunodeficiency caused by splenectomy, especially in children $^{31,32}$. Bradshaw and Thomas ${ }^{33}$ reported that the larger the remaining spleen, the most significant the protection against sepsis and they calculated that $25 \%$ of the critical mass of residual splenic tissue would restore normal phagocytic function. This suggestion is accepted by most authors. Van Wyck et al. ${ }^{34}$ in an experimental work with rats considered that it was necessary to maintain a third of the total splenic tissue to restore splenic function. In this work, subtotal splenectomy preserving the inferior pole kept about a third of the total splenic tissue.

When performing subtotal splenectomy, it is important to follow the technical care suggested by Paulo et al. ${ }^{20}$. The present study followed two other recommendations made by the author of the subtotal splenectomy technique ${ }^{17}$. The first one was to preserve the thin and transparent peritoneal fold extending from the anterior face of the greater curvature of the antrum to the anterior surface 
of the inferior splenic pole. This approach was adopted to keep the remaining fixed, i.e., with its cut surface facing anteriorly. The second one was not to fix the inferior pole below the greater curvature of the stomach, with the intention of preventing the twist of this remnant. Previous experience with the technique of subtotal splenectomy in rats showed that fixing the inferior pole in the stomach resulted in the high percentage of necrosis of this remnant. This phenomenon possibly occurred because fixing the inferior pole could compromise the blood supply of the inferior splenic pole due to the twist or traction of the small vessels of the pedicle. Thus, the inferior pole should be placed in the abdominal cavity with its cut surface facing toward the skull. After this maneuver, the greater omentum adheres naturally to the pole, which can be beneficial.

Hyperbaric oxygen therapy was performed according to the protocol suggested by Paulo et al. ${ }^{30}$. These authors suggested two sessions of HBO in the first three days and a daily session within seven days after STPI to improve the viability of the inferior pole or even accelerate its growth, as this treatment has an angiogenic effect.

In 1999, Paulo et al. ${ }^{17}$ reported signs of impairment of the viability and function of the inferior pole in dogs in the early postoperative period. Hence, the use of $\mathrm{HBO}$ in rats subjected to STPI could improve the viability of this remnant.

In this study there were no surgical complications. All animals which underwent STPI presented satisfactory recovery. Only one animal from subgroup B15 was excluded from the hyperbaric oxygen treatment because it presented, in the third postoperative day, after the session of $\mathrm{HBO}$, signs of dehydration: bristling hair, malaise and high upper respiratory frequency. Nevertheless, all animals survived.

HBO can help the animal lose weight, as demonstrated in a later study ${ }^{24,29}$. In this work, the animals subjected to this treatment lost weight during the first ten days and the group which was not submitted to the treatment gained weight during the same period. Possible causes of weight loss were the daily manipulation of the rats, their stay in the hyperbaric chamber during the period stipulated by the protocol and the stress resulting from the procedure. In this study, some animals treated with HBO showed chromodacryorrhea (tear red), which is indicative of stress or pain in rats.

Thus, it is interesting to quantify catecholamines and cortisol to compare the stress level of animals subjected to HBO treatment with those animals which were not treated with HBO. The viability of the inferior pole was detected macroscopically in $80 \%$ of the untreated animals (subgroup A15) and in $100 \%$ of the animals treated with hyperbaric oxygen (subgroup B15). This difference, however, was not significant. Microscopic analysis revealed that the animals in subgroup B15 (treated) compared to subgroup A1 5 (untreated) exhibited larger lymph follicles, a greater number of cells and vessels and higher lymphocytic proliferation. These data suggest a better viability of the inferior splenic pole in animals treated with hyperbaric oxygen than in those which were not treated (B15).

It is known that HBO has an angiogenic effect, which may have contributed to the results of this work. The protective effect of $\mathrm{HBO}$ on the inferior pole was already reported ${ }^{24}$. On $45^{\text {th }}$ day there was no difference in the viability of this pole between the subgroups treated and not treated with hyperbaric oxygen from the macroscopic point of view. However, there was a greater amount of vessels and cells in subgroup A45 compared to B45 in the microscopic evaluation, in relation to lymphoid follicles, lymphocytes and lymphocyte proliferation. This seems to indicate that HBO in the 45 day subgroup had an effect as striking as that in the subgroup of 15 days. It is important to remember that HBO was administered during the first ten days postoperatively and that the B45 subgroup received no such treatment for 35 days. Thus, during this period without treatment, the phenomena which occurred in subgroup A45 could have helped to avoid the macroscopic and microscopic differences between the inferior pole of the groups treated and not treated with hyperbaric oxygen. It should be emphasized that the morphological aspect does not necessarily have functional correspondence. Therefore, the tissue may be viable and appear normal even if it does not work properly ${ }^{35}$.

The growth of the inferior splenic pole has already been mentioned. Torres et al. ${ }^{23}$ in a model of subtotal splenectomy, different from the one in STPI, described the regeneration of this remnant in rats on the $45^{\text {th }}$ day. It was not known, however, if $\mathrm{HBO}$ could interfere with the growth of this pole. The present work is an attempt to settle this doubt. In this work, on the $15^{\text {th }}$ day, when the length, width and thickness of the pole were measured from the beginning to the end of the experiment, it was verified that the inferior pole did not grow in the animals treated or not with hyperbaric oxygen. However, in subgroups of 45 days this remainder grew. A significant increase in the length of the inferior splenic pole in subgroup A45 was obtained as well as an increase in the thickness of this pole in subgroup B45. It should be noted that the growth of this remnant is suggested by the fact that their average weight in animals of 45 days was markedly higher than in animals of 15 days not treated with hyperbaric oxygen.

In the treated animals, this pole was heavier in the group 
of 45 days, but not significantly. In the microscopic analysis, subgroups A45, B15 and B45, when compared to subgroup A15 showed increased lymphoid follicles, a great number of lymphocytes, higher cell proliferation and a great number of vessels. This suggests a further growth of the inferior pole of these subgroups. Although this growth has not occurred macroscopically in subgroup B15, microscopy shows signs of growth.

These results support the view that the morphological changes of the inferior splenic pole occur with the passing of time. Paulo et $a l .^{22}$ emphasized the improvement of lipid metabolism in the spleen. A recent study showed that the inferior pole grew significantly in length, width and thickness, from the $1^{\text {st }}$ to the $80^{\text {th }}$ day postoperatively, after STPI. The microscopic sign of this phenomenon was cell hyperplasia ${ }^{22}$. The inferior splenic pole grows for different reasons: the animal's growth, inflammation, and unknown factors. In this study, there was an increase in animal weight between the preoperative and postoperative periods in the groups treated or not with hyperbaric oxygen, on the $15^{\text {th }}$ and $45^{\text {th }}$ day. It is possible that on the $45^{\text {th }}$ day after surgery the initial inflammatory process has been minimized, and thus did not contribute to the growth of the inferior pole.

Studies on immunohistochemistry and molecular genetics are being developed to complement this work in order to clarify these issues.

\section{Conclusion}

Hyperbaric oxygen therapy did not affect the survival of animals but reduced their weight. It improved the viability of the inferior splenic pole, but did not interfere with their growth.

\section{References}

1. Crosby WH. An historical sketch of splenic function and splenectomy. Lymphology. 1983;16(2):52-5.

2. Feliciano DV, Bitondo CG, Mattox KL, Rumisek JD, Burch JM, Jordan GL Jr. A four-year experience with splenectomy versus splenorrhaphy. Ann Surg. 1985;201(5):568-75.

3. King H, Shumacker Jr HB. Splenic studies. Susceptibility to infection after splenectomy performed in infancy. Ann Surg. 1952;136(2):239-42.

4. Resende V, Petroianu A. Subtotal splenectomy fot treatment of severe splenic injuries. J Trauma. 1998;44(5):933-5.

5. Andersson R, Alwmark, Bengmark S. Outcome of pneumococcal challenge in rats after splenic artery ligation or splenectomy. Acta Chir Scand.1986;152:15-7.

6. Sugihara T, Yawata Y. Observations on plasma and red cell lipids in hereditary spherocytosis. Clin Chim Acta. 1984;137(2):227-32.

7. Aviram M, Brook JG, Tatarsky J, Levy Y, Carte A. Increased lowdensity lipoprotein levels after splenectomy: a role for the spleen in cholesterol metabolism in myeloproliferative disorders. Am J Med
Sci. 1986;291(1):25-8.

8. Asai K, Kuzuya M, Naito M, Funaki C, Kuzuya F. Effects of splenectomy on serum lipids and experimental atherosclerosis. Angiology. 1988;39(6):497-504.

9. Paulo DNS, Lázaro da Silva A. Lipídeos plasmáticos após esplenectomia total e parcial em cães. Rev Col Bras Cir. 2001;28(3):264-70.

10. Paulo ICAL, Paulo DNS, Lázaro da Silva A, Foletto RM, Colnago GL, Vargas PM. Níveis de lípides plasmáticos em ratos submetidos à esplenectomia total, ligadura simultânea dos vasos esplênicos e a esplenectomia subtotal com preservação do pólo inferior. Rev Col Bras Cir. 2005;32(5):229-36.

11. Petroianu A, Veloso DFM, Costa GR, Alberti LR. Efeitos de operações sobre o baço no lipidograma de ratas. Rev Assoc Med Bras. 2006;52(1):56-9.

12. Warshaw AL. Conservation of the spleen with distal pancreatectomy. Arch Surg. 1988;123(5):550-3.

13. Zilberstein B, Sallet JA, Ramos A, Eshkenazy R. Video laparoscopy for the treatment of bleeding esophageal varices. Surg Laparosc Endosc. 1997;7(3):185-91.

14. Mignon F, Brouzes S, Breitel DL, Bastie JN, Poirier H, Legendre C, Briard P. Preoperative selective embolization allowing a partial splenectomy for splenic hamartome. Ann Chir. 2003;128(2):112-6.

15. Campos-Christo M. Esplenectomias parciais regradas. O Hospital. 1959; 56(4): 93-8.

16. Petroianu A. Esplenectomia subtotal e anastomose esplenorrenal proximal para o tratamento da hipertensão portal. Rev Bras Cir. 1983;73(3):101-4.

17. Paulo DNS, Lázaro da Silva A, Cintra LC, Bof AM, Santiago DC, Ribeiro GB. Esplenectomia subtotal, em cães, com preservação do pólo inferior suprido por vasos do ligamento gastroesplênico. Rev Col Bras Cir. 1999; 26(3): 147-52.

18. Marques RG. Autoimplante esplênico em ratos: regeneração morfológica e função fagocitária [tese-Doutorado]. Belo Horizonte: Faculdade de Medicina da Universidade Federal de Minas Gerais; 2001.

19. Resende V, Petroianu A, Junior WC. Autotransplantation for treatment of severe splenic lesions. Emerg Radiol. 2002;9(4):20812.

20. Paulo DNS, Paulo ICAL, Kalil M, Vargas PM, Lázaro da Silva A, Baptista JFA, Guerra AJ. Subtotal splenectomy preserving the lower pole in rats: technical, morphological and functional aspects. Acta Cir Bras. 2006;21(5):321-7.

21. Paulo ICAL, Paulo DNS, Cintra LC, Santos MCS, Rodrigues H, Ferrari TA, Azevedo TC, Silva AL. Preservative spleen surgery and hiperbaric oxygen therapy. Acta Cir Bras. 2007;22 Suppl 1:21-8.

22. Paulo DN, Ramos BF, Zanetti FR, Marques T, Cintra LC, Lemos Paulo IC, Silva AL. Growth of the lower spleen pole remaning after subtotal splenectomy in rats. Acta Cir Bras. 2008;23(2):125-9.

23. Torres OJM, Macedo EL, Picciani ERG, Nunes PMS, Costa JVG, Carvalho AB, Lobato Junior PS. Estudo histológico da regeneração esplênica de ratos submetidos a esplenectomia subtotal. Acta Cir Bras. 2000;15(2):1-12.

24. Paulo ICAL, Paulo DNS, Ferrari TA, Azeredo TCV de, Lázaro da Silva A. O pólo inferior do baço de ratos e a oxigenoterapia hiperbárica. Rev Assoc Med Bras. 2008;54(1):77-81.

25. Muhonen A, Haaparanta M, Grönroos T, Bergman J, Knuuti J, Hinkka S, Happonen RP. Osteoblastic activity and RM neoangiogenesis in distracted bone of irradiated rabbit mandible with or without hyperbaric oxygen treatment. Int J Oral Maxillofac Surg. 2004;33(2):173-8.

26. Burt JT, Kapp JP, Smith RR. Hyperbaric oxygen and cerebral infarction in the gerbil. Surg Neurol. 1987;28(4):265-8.

27. Costa-Val R, Nunes TA, Oliveira e Silva RC, De Puy e Souza TK. 
Efeitos da oxigenoterapia hiperbárica em ratos submetidos à ligadura das veias hepáticas: avaliação da mortalidade e da histologia do fígado e baço. Acta Cir Bras. 2006;21(1):1-19.

28. Juang JH, Hsu BR, Kuo CH, Uengt SW. Beneficial effects of hyperbaric oxygen therapy on islet transplantation. Cell Transplant. 2002;11(2):95-101.

29. Paulo ICAL, Silva AL, Piras C, Ramos BF, Zanetti FR, Paulo DNS. Aspectos morfológicos e funcionais dos autoimplantes esplênicos em ratos tratados com oxigenio hiperbárico. Rev Col Bras Cir. 2010;37(3):226-33.

30. Paulo DNS, Kalil M, Grillo Júnior LSP, Borges EB, Cintra LC, Pereira FEL, Lázaro da Silva A. Viabilidade do baço após a ligadura dos vasos esplênicos: efeito do tratamento com oxigênio hiperbárico. Rev Assoc Med Bras. 2005;51(1):46-50.

31. Revuelta Alvarez S, Fernandez-Escalante C, Casanova Rituerto D, Lopez Espadas F, Martin Fernandez J. Assessment of postsplenectomy residual splenic function. Splenic autotransplants. Int Surg. 1987;72(3):149-53.

32. Witte CL, Esser MJ, Rappaport WD. Updating the management of salvageable splenic injury. Ann Surg. 1992;215(3):261-5.

33. Bradshaw PH, Thomas CG Jr. Regeneration of splenic remnants after partial splenectomy in rats. J Surg Res. 1982;32(2):176-81.

34. Van Wyck DB, Witte MH, Witte CL, Thies AC Jr. Critical splenic mass for survival from experimental pneumococcemia. J Surg Res. 1980;28(1):14-7.

35. Rezende AB, Nunes SI, Farias RE, Vieira FR, Petroianu A, Teixeira HC. Influência do baço, da asplenia e do implante esplênico autógeno no metabolismo lipídico de camundongos. Rev Col Bras Cir. 2007;34(3):177-82.

\section{Acknowledgments}

Department for Support of Clinical and Experimental Research of the Institute for Sustainable Development of Espirito Santo (Brazil) for financial support.

The students of Medicine (EMESCAM), Aline Trugilho Ferrari, Flávia Vieira de Freitas, Jorge Zoghaib and Marcus Alexandre Novo Brazolino for their support during the experimental procedures.

\section{Correspondence:}

Tarcizo Afonso Nunes

Rua Professor Estevão Pinto, 637/1104

30220-060 Belo Horizonte - MG Brasil

Phone: (55 31)3409-9632 / 9983-0110

tan@medicina.ufmg.br
Conflict of interest: none Financial source: FAPES

Received: November 16, 2010

Review: January 18, 2011

Accepted: February 16, 2011 